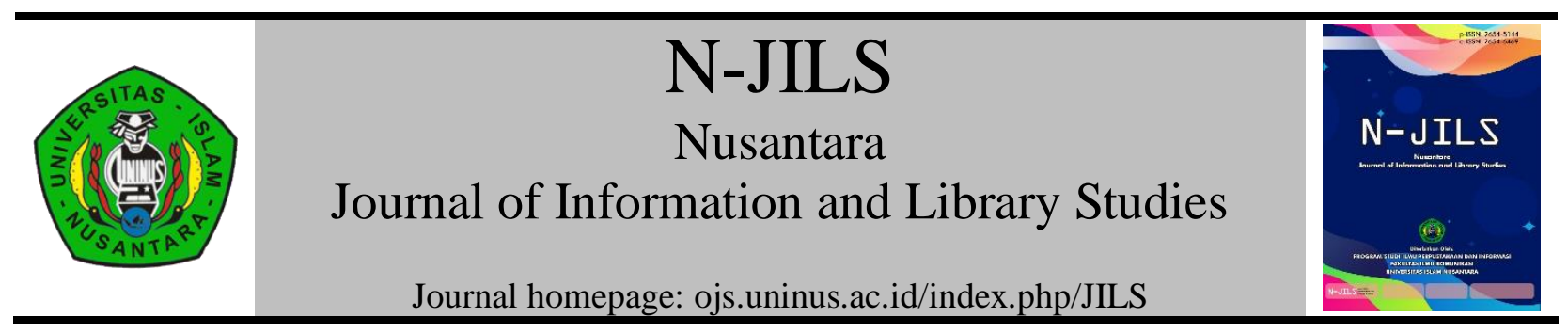

\title{
Literasi Data Dan Tantangan Industrialisasi 4.0 Bagi Masyarakat Pesisir Di Indonesia
}

\section{Data Literacy And Challenges Of Industrialization 4.0 For Indonesian Coastal Communities}

\section{Dian Kristyanto \\ Universitas Wijaya Kusuma Surabaya e-mail: diankristyanto@uwks.ac.id}

\begin{tabular}{ll}
\hline ARTICLE INFO & ABSTRACT \\
\cline { 2 - 3 } Article history & Industrialization 4.0 brought many changes to the \\
Revised [October, 2020] & community, especially in terms of sustainable internet \\
Accepted [December, 2020] & usage. Data literacy arises because of the large amount of \\
Available Online [December, 2020] & data and information spread on the internet. This objective \\
study to provide knowledge about data literacy in coastal \\
society, another purpose is to explain the challenges that \\
arise as a result of the birth industrialization 4.0 which \\
certainly also felt by the coastal community. This \\
methodology uses a literature review approach. Data \\
collection techniques are carried out through studies of \\
reference sources that are used as references. This study \\
discussion is that data literacy in coastal society is devoted \\
to basic knowledge in protecting personal data when \\
conducting activities using the internet. Public-private data \\
that needs to be kept secret include; identity number, \\
account number, full name, telephone number, password, \\
address, and others. While the challenges faced by coastal \\
society in the industrialization 4.0 cover many aspects, \\
three main challenges can be felt directly by coastal society \\
such as big data, internet objects, and robotization.
\end{tabular}

Keyword: coastal communities; data literacy; industrialization 4.0; information technology 
Kata kunci: industrialisasi 4.0; literasi data; masyarakat pesisir; teknologi informasi

\begin{abstract}
ABSTRAK
Industrialisasi 4.0 membawa banyak perubahan bagi masyarakat terutama dalam hal pemanfaatan internet secara terus-menerus. Literasi data muncul karena banyaknya data dan informasi yang tersebar di internet. Penelitian ini bertujuan untuk memberikan pengetahuan mengenai literasi data pada masyarakat pesisir, tujuan lain adalah untuk menjelaskan tantangan yang muncul akibat dari lahirnya era industrialisasi 4.0 yang pastinya dirasakan juga oleh masyarakat pesisir (nelayan). Metodologi menggunakan pendekatan riset pustaka. Proses pengumpulan data dilakukan dengan cara telaah terhadap sumber referensi yang digunakan sebagai rujukan. Kajian ini menghasilkan pembahasan bahwa literasi data pada masyarakat pesisir dikhususkan pada pengetahuan dasar dalam menjaga data pribadi pada saat melakukan aktifitas menggunakan internet. Data pribadi masyarakat yang perlu dijaga kerahasiaannya meliputi: nomor identitas, nomor rekening, nama lengkap, nomor telepon, password, alamat tinggal dan sebagainya. Sedangkan tantangan yang dihadapi masyarakat pesisir di era industrialisasi 4.0 meliputi banyak aspek, namun terdapat tiga tantangan utama yang dapat dirasakan secara langsung oleh masyarakat pesisir seperti big data, internet of thing dan robotization.
\end{abstract}

(C) 2020 NJILS. All rights reserved.

\section{A. PENDAHULUAN}

Teknologi saat ini tidak hanya digunakan sebagai alat, namun manusia dapat menjadikan teknologi sebagai teman, rekan kerja dan sebagainya. Hampir setiap orang memiliki smartphone yang digunakan setiap waktu, setiap individu bahkan memiliki lebih dari satu gadget untuk mendukung komunikasi dan eksistensi sebagai manusia sosial yang aktif di dua dunia (dunia nyata dan virtual). Hasil survei yang dilakukan oleh Pew Research Center yang merupakan lembaga penelitian berbasis di Amerika Serikat pada tahun 2018 menyebutkan jika Indonesia sebagai negara berkembang memiliki pertumbuhan pengguna smartphone yang lumayan tinggi, untuk pengguna muda (kisaran usia 18-34 tahun) kepemilikan smartphone mengalami peningkatan yaitu dari $39 \%$ menjadi $66 \%$ dari tahun 2015-2018. Sedangkan untuk pengguna HP berusia tua (usia 50 tahun ke atas), pengguna smartphone mengalami kenaikan prosentase dari $2 \%$ pada tahun 2015 menjadi $13 \%$ pada tahun 2018 (Alfarizi, 2019). Hasil survei ini menunjukkan jika memang masyarakat 
Indonesia mengalami peningkatkan terhadap konsumsi komoditas teknologi yang mudah digunakan dan diakses seperti smatphone yang memiliki banyak fitur serta mudah untuk dibawa kemana saja.

Teknologi membawa perubahan terutama dari sisi kemudahan akses informasi bagi masyarakat, sebelumnya informasi cenderung diperoleh melalui media cetak yang hanya dapat dibaca pada waktu-waktu tertentu dan berbayar, kemudian informasi dapat diperoleh melalui media elektronik seperti radio dan televisi namun informasi yang tersaji jumlahnya terbatas. Saat ini jumlah informasi tidak lagi terbatas, setiap detik informasi tersebar sangat cepat melalui media sosial, portal berita online dan sebagainya. Hal ini terjadi karena perkembangan teknologi yang dibuat oleh manusia membuka gerbang peradaban baru yang dikenal dengan era digitalisasi.

Digitalisasi membuat informasi tersebar begitu luas di masyarakat, informasi dari beragam bidang dan berasal dari berbagai penjuru dunia dapat diakses melalui internet. Penggunaan domain sebagai etalase dunia maya juga terus meningkat, pengguna domain sendiri tidak hanya di dominasi institusi/organisasi tetapi juga perorangan mulai berani untuk menggunakan domain sebagai jalan masuk membuka etalase digital. Sebagai satu contoh, pengguna domain Indonesia (.id) mengalami pertumbuhan signifikan pada tahun 2019, pengguna domain .id mengalami kenaikan sebesar 45\% menjadi 135.812 nama domain baru, jumlah ini lebih tinggi daripada domain nasional lain seperti domain co.id (Wardani, 2020).

Informasi dan data di era digitalisasi seakan menjadi komoditas yang sangat mudah diperoleh, dengan kecanggihan teknologi hardware dan software berbasis jaringan memberikan kemudahan bagi masyarakat maupun organisasi untuk mendapatkan informasi dan data. Pada akun media sosial, masyarakat sangat terbuka menampilkan identitas personal pada masyarakat seperti nama lengkap, alamat, email, status, dan lainnya. Selain itu pada portal-portal online tertentu masyarakat begitu mudah untuk memberikan data pribadi hanya karena ingin menjadi bagian dari portal-portal tertentu yang menggunakan dapat diakses dengan cara melakukan registrasi terlebih dahulu.

Akses internet saat ini telah menjadi semacam kebutuhan primer bagi semua kalangan, penggunaan internet sudah tidak lagi dibatasi masalah status ekonomi masyarakat karena saat ini pemanfaatan smartphone telah menjamur hampir di berbagai lapisan sosial masyarakat. Penggunaan internet yang masif memang dapat menunjukkan bahwa 
masyarakat diberbagai golongan sudah mulai melek terhadap teknologi, akan tetapi disatu sisi kemasifan tersebut dapat memberikan dampak negatif apabila pemanfaatan internet di beberapa lapisan masyarakat tidak diimbangi dengan proses berpikir rasional serta keterampilan literasi yang dapat membantu seseorang untuk lebih teliti dan bijak menggunakan internet. Setiap golongan masyarakat memiliki kondisi ekonomi dan pendidikan yang berbeda, dalam hal ini golongan masyarakat pesisir masuk dalam kategori masyarakat pinggiran yang hidup dalam keterbatasan pendidikan dan lebih memilih bekerja di laut untuk memenuhi kebutuhan hidup. Masyarakat pesisir saat ini memang sebagian telah mengenal adanya internet, hal sama juga dikemukakan oleh Setriawati, Suryaningsih dan Solina (2018) yang menjelaskan bahwa masyarakat nelayan di Tanjung Unggat, Kepulauan Riau telah mengenal internet, dan para nelayan telah memiliki kecenderungan menggunakan smartphone untuk mencari kebutuhan nelayan yang akan digunakan saat sedang kelaut maupun di darat.

Persoalan yang dihadapi masyarakat pesisir ditengah mulai masifnya pemanfaatan internet adalah bahwa dengan latar belakang pendidikan yang masih rendah berpotensi membuat mereka tidak memiliki kontrol terhadap penggunaan internet. Hal ini dapat berdampak buruk ketika masyarakat menjadi sangat terbuka memberikan data dan informasi yang mereka miliki lalu disebarkan ke internet. Pemahaman tentang data dan bagaimana cara menjaganya di era yang sangat terbuka ini dibutuhkan oleh masyarakat pesisir terutama yang masih baru mengenal perkembangan jaman. Oleh sebab itu, dibutuhkan suatu keterampilan berliterasi yang harus dimiliki masyarakat pesisir supaya dapat menjaga data yang mereka miliki sehingga mereka dapat mengakses internet dengan aman dan nyaman. Berangkat dari permasalahan yang muncul tentang industrialisasi 4.0, data dan informasi serta kaitannya dengan masyarakat pesisir dimunculkan sebuah rumusan masalah tentang bagaimana konsep literasi data dan tantangan yang muncul di era industrialisasi 4.0 bagi masyarakat pesisir.

\section{B. TINJAUAN PUSTAKA}

Literasi data dan industrialisasi 4.0 telah banyak dibahas pada forum-forum ilmiah di skala nasional maupun internasional. Penelitian yang mengkaji tentang literasi data dan industrialisasi 4.0 juga cukup banyak karena memang menjadi kajian yang sangat menarik di era informasi sekarang ini. Beberapa kajian tentang literasi data selama lima tahun terakhir 
seperti kajian yang dilakukan oleh Erwin (2015) dengan judul Data Literacy: Real-World Learning Through Problem-Solving With Data Seat, dimana dalam kajiannya menitikberatkan pada siswa sebagai objek yang diteliti. Hasil kesimpulan dalam kajiannya menjelaskan jika siswa yang dapat melakukan analisis terhadap kumpulan data yang diperoleh akan dapat memperluas dan memperdalam pengetahuan serta keterampilan di disiplin pengetahuan, mampu berpikir seperti layaknya para ahli dalam disiplin ilmu tertentu dan lebih dapat menghargai hasil pemikiran para ahli melalui data yang mereka peroleh.

Kajian berikutnya mengenai literasi data dilakukan oleh Murray-Rust, et.al (2019) dengan judul Data Literacy as Pathway to Data Science at Georgia Tech yang terbit pada jurnal Research Library Issues pada tahun 2019. Kajian ini menfokuskan pada perpustakaan perguruan tinggi sebagai pusat data. Kajian ini menghasilkan kesimpulan program literasi data diharapkan tumbuh dan berubah seiring dengan perubahan kebutuhan mahasiswa disetiap fakultas. Untuk mengembangkan keterampilan mahasiswa dan meningkatkan peran fakultas yang melek data maka perpustakaan perlu mencari data untuk memenuhi kebutuhan penggunanya, melakukan kemitraan dan menghasilkan sumber daya yang dapat menjadi agen yang cerdas untuk melatih mahasiswa di setiap fakultas. Kajian selanjutnya datang dari penelitian yang dilakukan oleh Javorsky, Koltay \& Muranyi (2019), kajian yang dilakukan melalui metode survei online dilakukan oleh peneliti pada tahun 2018 tentang literasi data oleh para peneliti di Hungaria yang mencakup sekitar 108 peneliti. Hasil analisis dari penelitian ini menjelaskan jika peneliti menyoroti kesamaan dan perbedaan dari tanggapan dan saran dari para peneliti asing tentang langkah-langkah yang harus diambil untuk modernisasi pengetahuan seperti pelatihan manajemen data, penggunaan data secara bersama-sama dan berbagi data.

Kajian lain mengenai industrialisasi 4.0 dilakukan oleh Daribay, Serikova \& Ukaegbu (2019) melalui artikel berjudul Industry 4.0: Kazakhstani Industrialization Needs a Global Perspective yang diterbitkan pada tahun 2019. Pendapat para peniliti dalam kajian ini menyatakan jika implementasi industialisasi 4.0 di Kazakhstan telah dilakukan oleh berbagai perusahaan besar di negara tersebut dengan penerapan standar global dalam pengembangan perusahaan guna mendukung peningkatan produktifitas dan meningkatkan daya saing perusahaan di level internasional. Penelitian tentang masyarakat pesisir atau yang dikenal dengan masyarakat nelayan pernah dilakukan oleh Tristania (2016), penelitian ini fokus pada pengembangan peran edukasi dan diseminasi informasi yang dilakukan oleh 
penyuluh perikanan bagi masyarakat nelayan di Kabupaten Serdang Bedagai Sumatera Utara, Indonesia. Penelitian ini menggunakan metode deskriptif dengan pendekatan kualitatif dan pengumpulan datanya menggunakan Focus Group Discussion (FGD). Hasil dari penelitian ini menunjukkan jika ada keterbatasan tenaga penyuluh dan koneksi internet sehingga peran penyuluh terhadap diseminasi informasi dan edukasi juga sangat terbatas. Akan tetapi sebagai proses pengembangan diseminasi informasi para penyuluh menyediakan media elektronik yang digunakan untuk menyajikan informasi seperti pembuatan website, perangkat televisi, menyediakan layanan telepon dan SMS sebagai pusar komunikasi para nelayan dan membuat program e-learning.

\section{METODE PENELITIAN}

Penelitian ini mengkaji tentang konsep literasi data serta tantangan industrialisasi 4.0 yang pasti dirasakan oleh masyarakat luas khususnya masyarakat pesisir (nelayan). Kajian ini tentu bertujuan untuk memberikan pemahaman dan pengetahuan tentang literasi data pada masyarakat pesisir, selanjutnya tujuan lain dari kajian ini adalah untuk menjelaskan bentuk-bentuk tantangan apa saja yang muncul akibat dari lahirnya era industrialisasi 4.0 yang pastinya dirasakan juga oleh masyarakat pesisir (nelayan). Metode yang digunakan dalam kajian ini yaitu dengan pendekatan riset kepustakaan. Tinjauan pustaka menurut Efron \& Ravid (2019) adalah proses telaah terhadap literatur ilmiah tentang topik tertentu yang dilakukan secara sistematis, dalam meninjau literatur, peneliti harus menyajikan pemahaman yang komprehensif, kritis dan akurat tentang keadaan pengetahuan yang diamati; membandingkan berbagai penelitian dan teori yang digunakan dalam penelitian; mengungkapkan kesenjangan di dalam sebuah literatur; dan melakukan pengembangan untuk terhadap topik yang diteliti. Uraian dalam literatur review diarahkan untuk menyusun kerangka pemikiran yang jelas tentang pemecahan masalah yang sudah diuraikan di dalam rumusan masalah. Studi kepustakaan berisi ulasan, rangkuman, dan pemikiran penulis tentang beberapa sumber pustaka (berupa artikel, buku, slide, informasi dari internet dan sebagainya) tentang topik yang dibahas. Teknik pengumpulan data dalam kajian ini melalui telaah terhadap sumber referensi yang digunakan sebagai rujukan. 


\section{HASIL DAN PEMBAHASAN}

\section{Konsep Literasi Data dan Penerapannya Bagi Masyarakat Pesisir}

Istilah literasi data belum banyak dikenal oleh masyarakat, walaupun kata literasi sendiri bukanlah sebuah istilah baru karena secara harfiah literasi dikenal sebagai keberaksaraan. Literasi pada dasarnya sudah tercermin sebagai salah satu tujuan dalam Undang-Undang Dasar Republik Indonesia tahun 1945 yaitu mencerdaskan kehidupan bangsa, artinya bahwa istilah literasi sebenarnya sudah menjadi visi dari Negara untuk menjadikan masyarakatnya memiliki peradaban yang cerdas dan terbuka terhadap pengetahuan. Literasi sering dikaitkan dengan proses membaca dan menulis, menurut Freire \& Macedo (1987) menjelaskan literasi sebagai proses pemahaman yang kritis dalam kegiatan membaca dan menulis. Menurut UNESCO dalam Potter \& McDougall (2017) menjelaskan bahwa literasi merupakan hak asasi manusia yang paling dasar dan menjadi pondasi untuk belajar sepanjang hayat, literasi bagi indivudi, keluarga maupun masyarakat menjadi instrumen pemberdayaan yang digunakan untuk meningkatkan kesehatan, pendapatan (kesejahteraan hidup) dan menjalin hubungan seseorang dengan dunia. Definisi literasi menjadi berkembang lebih luas seiring dengan perkembangan ilmu pengetahuan dan adanya kebutuhan sosial masyarakat yang lebih kompleks. Literasi saat ini dapat dikolaborasikan dengan berbagai bidang keilmuan, seperti literasi politik, literasi sosial, literasi digital, literasi sekolah dan sebagainya. Hal ini menunjukkan jika kata literasi bukan hanya sekedar terkait dengan aktifitas membaca dan menulis namun sudah masuk pada proses pemahaman hingga implementasi terkait bidang-bidang tertentu. Potter \& McDougall (2017) mendefinisikan literasi dengan istilah "Melek" artinya bahwa literasi tidak hanya sekedar tentang apa yang seseorang pelajari tetapi bagaimana seorang menjalankan proses belajar hingga memahami artinya menjadi pembelajar.

Seiring dengan masuknya literasi di berbagai bidang yang berkaitan dengan masyarakat, maka dalam perkembangan teknologi informasi muncul istilah literasi informasi dan literasi data. Literasi di dalam arus teknologi sangat penting dipelajari oleh masyarakat karena perkembangan teknologi harus dihadapi sehingga kelompok-kelompok masyarakat tertentu tidak tergerus oleh perubahan jaman yang berjalan begitu cepat. Setiap orang tentunya familiar dengan data, bahkan kehidupan manusia modern tidak lepas dari data yang sifatnya umum maupun pribadi. Data secara estimologi dijelaskan oleh Borgman (2007) dalam Kitchin (2014) berasal dari bahasa latin "Dare” yang berarti "memberi”, dalam 
pengertian ini data diartikan sebagai elemen mentah yang dapat diambil dari sebuah fenomena atau fakta di masyarakat, akan tetapi dalam penggunaan secara umum, data merupakan elemen-elemen yang diambil melalui proses pengamatan, perhitungan, percobaan dan penyimpanan arsip atau catatan-catatan penting. Konsep literasi data menurut Yun Dai (2019) merupakan cara berpikir kritis yang diterapkan untuk proses evaluasi sumber data dan cara melakukan penafsiran serta mengkomunikasikan kembali data yang diperoleh.

Di dalam sebuah masyarakat khususnya yang tinggal di daerah pantai, keberadaan data sangatlah penting. Hal ini karena data dapat menunjukkan identitas masyarakat sebagai warga negara, selain itu data digunakan untuk keperluan administratif hingga pada proses ekonomi dan bisnis. Perkembangan teknologi yang sangat pesat, membuat masyarakat khususnya yang berdomisili di daerah pantai (pesisir) harus membiasakan diri untuk lebih terbuka pada kelompok lain terutama dalam segi komunikasi yang terjadi melalui jejaring media sosial online. Oleh karena itu untuk menghadap era baru yang lebih terbuka, dan sebaran arus informasi yang pesat menuntuk masyarakat untuk lebih terbuka terhadap data pribadinya. Hal ini dapat dilihat dari kebiasaan masyarakat berkomunikasi melalui media sosial (Facebook, Twitter, Instagram, Whattsapp dan sebagainya). Muncul kebiasaan dari masyarakat yang baru mengenal teknologi, dimana kebiasaan tersebut cenderung mengajak masyarakat untuk sangat terbuka membuka data pribadi. Contoh yang paling mudah dapat dilihat dari seringnya masyarakat memberikan kontak/nomor ponsel pribadi pada masyarakat umum melalui halaman jejaring sosial. Hal ini menunjukkan bahwa kesiapan masyarakat terutama yang tinggal di daerah pinggiran masih sangat kurang sehingga muncul kecerderungan mereka mudah terlena beraktifitas di internet.

Masyarakat pesisir atau sering dikenal dengan masyarakat nelayan sebagian besar hidupnya bergantung dari hasil laut. Berbeda dengan masyarakat lain seperti di perkotaan, masyarakat pesisir memiliki karakteristik yang cenderung lebih keras, memiliki sifat yang kaku dan lebih memilih menghabiskan waktu untuk bekerja. Menurut Kusnadi (2017) masyarakat pesisir atau masyarakat nelayan di berbagai kawasan secara umum memiliki ciri yang sama seperti kemiskinan, keterbelakangan sosial-budaya, rendahnya kualitas sumber daya manusia karena sebagian besar penduduk hanya lulusan sekolah dasar dan kapasitas berorganisasi masyarakat yang rendah. Masyarakat pesisir juga rentan bahaya karena adanya potensi terdampak bencana alam, faktor inilah yang mengakibatkan masyarakat pesisir 
berada di garis kemiskinan dan memiliki pendidikan yang rencah. Buot \& Dulce (2018) melakukan penelitian di Filipina pasca terjadinya bencana alam Topan Haiyan. Temuan penelitian menunjukkan bahwa masih banyak keluarga yang memiliki kualifikasi pendidikan minimum sehingga berdampak pada proses mendapatkan pekerjaan. Masyarakat pesisir masih memiliki banyak persoalan terhadap kesejahteraan sosial. Hal ini tentu dapat mempengaruhi cara mereka untuk menerima perkembangan globalisasi secara menyeluruh.

Perkembangan global pada dasarnya membawa perubahan signifikan di berbagai sektor khususnya pada wilayah industri. Banyak lahan kosong berubah fungsi menjadi lahan industri karena adanya kebutuhan dari masyarakat untuk memperoleh pendapatan dengan menjual lahan yang dimiliki. Hal ini juga terjadi di masyarakat pesisir, banyak area pertambakan yang mulai beralih fungsi karena telah dibeli oleh para pemilik modal untuk dijadikan pabrik. Oleh karena itu, masyarakat pesisir yang awalnya mengandalkan lahan tambak untuk bekerja harus kembali mengandalkan hasil laut supaya dapat bertahan hidup. Industrialisasi saat ini tumbuh pesat karena di dorong oleh perkembangan teknologi informasi, mereka yang tidak mampu berinovasi dan cenderung melawan arus justru akan tersisih dari era industrialisasi global.

Masyarakat pesisir pada dasarnya cenderung pasif menanggapi perkembangan teknologi informasi, bagi mereka selama alam masih memberikan hasil laut untuk ditangkap maka perkembangan era tidak akan berpengaruh terhadap mereka. Akan tetapi muncul permasalahan disaat media elektronik mulai mempengaruhi cara pikir masyarakat pesisir dengan memberikan iklan-iklan maupun tontonan yang cenderung menampilkan kecanggihan teknologi informasi seperti smartphone, laptop, dan internet. Tontonan yang diberikan oleh media elektronik cenderung mudah diterima oleh masyarakat pesisir terutama oleh generasi muda dan kalangan wanita karena keseharian mereka yang dihabiskan untuk berada di rumah.

Penggunaan teknologi informasi seperti gadget dan internet sudah tidak dapat diatasi lagi, sudah banyak dari generasi muda dan kalangan wanita yang tinggal di daerah pesisir mulai menggunakan fasilitas teknologi informasi. Aktifitas anak muda di masyarakat pesisir setiap harinya tidak lepas dari smartphone dan internet, mereka mulai mengenal media jejaring sosial untuk menghubungkan mereka dengan dunia luar, selain itu para wanita mulai mengenal belanja online sehingga mereka mulai tertarik untuk membeli kebutuhan pokok seperti baju, celana, sepatu dan lain sebagainya melalui portal belanja online seperti shopee, 
lazada, bukalapak dan lainnya. Karakteristik masyarakat pesisir yang keras dengan didukung dengan kurangnya pendidikan yang mereka tempuh sebagaimana ciri-ciri masyarakat nelayan yang hanya tamatan sekolah menengah, maka keberadaan teknologi informasi membawa masalah baru bagi masyarakat pesisir. Perkembangan teknologi informasi yang pesat melahirkan pihak-pihak yang ingin meraup keuntungan besar ditengah masifnya penggunaan teknologi oleh masyarakat di Indonesia. Sebagai negara dengan jumlah penduduk terbesar, maka Indonesia menjadi ladang data yang sangat menguntungkan bagi beberapa pihak yang ingin memanfaatkannya untuk mendapatkan keuntungan yang besar. Masyarakat pesisir menjadi salah satu target untuk diambil datanya melalui aktifitas yang mereka lakukan di internet seperti bermedia sosial, belanja online dan sebagainya.

Masyarakat pesisir kemungkinan tidak akan berpikir jauh tentang data pribadi yang mereka gunakan di internet. Masalah yang muncul disini adalah masyarakat pesisi bisa jadi sangat terbuka dengan data pribadi mereka sehingga tidak adanya filter keamanan dari masing-masing individu untuk tidak membuka akses secara berlebihan terhadap data mereka di internet. Penggunaan teknologi informasi yang berlebihan dapat membawa candu bagi masyarakat pesisir, apabila tidak segera diatasi maka mereka dapat menjadi korban dari kriminalisasi data yang sering muncul akibat dari perkembangan teknologi informasi. Literasi data menjadi salah satu solusi penanggulangan karena saat ini sangat tidak mungkin melarang masyarakat pesisir untuk berselancar di internet.

Penerapan literasi data pada masyarakat pesisir tentunya harus mulai dilakukan, hal ini untuk mengantisipasi adanya kelalaian yang berakibat pada hilangnya privasi masyarakat pesisir di dunia maya (internet). Fontichiaro (2019) berpendapat bahwa literasi data penting dilakukan mengingat data di internet jenisnya sangat beragam. Data di internet tidak hanya berupa angka, terkadang data dapat menyerupai informasi, data saat ini seakan menjadi milik bersama karena mudah diakses melalui internet. Sangat sulit untuk tidak memberikan data pribadi kita apabila sedang ingin berselancar di internet, menggunakan media sosial seperti facebook, twitter dan lainnya juga mengharuskan kita untuk memberikan data pribadi, berbelanja online juga mengharuskan untuk memberikan data pribadi, hal inilah yang dapat menyulitkan masyarakat umum khususnya yang tinggal didaerah pesisir untuk tidak terbuka terhadap data pribadinya.

Penerapan literasi data pada masyarakat pesisir dapat dimulai dengan pendidikan data pribadi yang harus dijaga oleh masing-masing individu. Literasi data mencakup 
kemampuan belajar, bekerja, menganalisis, dan membangun pendapat dengan berlandaskan pada data yang dapat diperoleh secara luas di seluruh dunia (D'Ignazio 2017; D'Ignazio \& Bhargava 2016; Letouze et al 2015). Penerapan literasi data pada masyarakat pesisir secara umum dilakukan sama dengan masyarakat lain, dimana penerapan tersebut menekankan pada aspek keterampilan membaca, menganalisis hingga menggunakan data. Hal ini juga dikemukakan oleh Alfin (2018) yang menjelaskan bahwa literasi data terkait dengan kemampuan membaca, menganalisis, dan membuat konklusi berpikir berdasarkan data dan informasi yang diperoleh. Penerapan literasi data mengajak masyarakat untuk lebih peduli terhadap data yang dimiliki sekaligus memberikan pembelajaran tentang cara menggunakan data yang diperoleh melalui internet. Penerapan literasi data pada masyarakat pesisir dapat dilakukan secara menyeluruh, namun hal itu dapat menyita waktu yang banyak mengingat karakteritik masyarakat pesisir yang keras, dan tidak terbiasa untuk belajar secara cepat. Oleh karena itu, penerapan literasi data dijalankan dengan cara memberikan dasar-dasar pengetahuan tentang konsep literasi, internet dan pentingnya menjaga keamanan data pribadi seperti nama lengkap, nomor kependudukan, alamat tinggal, nomor telepon, dan tanggal lahir.

Data tersebut merupakan identitas pribadi yang melekat pada setiap individu yang bersifat rahasia (penting), sehingga masyarakat harus memberikan keamanan yang lebih supaya data ini tidak mudah untuk diakses oleh orang lain di internet. Literasi data selanjutnya terkait dengan data keuangan yang mana saat ini telah banyak masyarakat menggunakan fasilitas perbankan untuk transaksi sekaligus menyimpan harta. Data keuangan seperti nomor rekening, nama, password (PIN) dan nomor kartu ATM (Anjungan Tunai Mandiri) perlu digunakan secara benar. Literasi data keuangan penting dimiliki oleh masyarakat yang saat ini mulai cenderung melakukan pembelian secara online, mekanisme pembayaran online memang memudahkan masyarakat namun juga harus tetap diwaspadai karena rawan sekali data transaksi kita sering diambil secara ilegal oleh oknum yang berkepentingan.

Penerapan literasi data pada dasarnya harus dilakukan pada seluruh masyarakat pesisir seperti pada remaja sekolah, ibu rumah tangga serta kepala rumah tangga sehingga mereka mulai membiasakan diri menjaga privasi pada saat melakukan interaksi dengan internet. Penerapan literasi data dapat dilakukan oleh para perangkat desa, tokoh masyarakat, dinas pemerintahan dan akademisi melalui program penyuluhan literasi data secara merata 
dan berkelanjutan. Selain itu pembuatan "rumah literasi” juga sangat perlu untuk menjaga sekaligus wadah yang mengakomodasi masyarakat untuk belajar tentang tata cara berliterasi di era teknologi informasi.

\section{Tantangan Industrialisasi 4.0 Bagi Masyarakat Pesisir}

Literasi data erat kaitannya dengan industrialisasi 4.0, hal ini karena data dan informasi menjadi komoditas mahal di era internet. Menurut Throgmorton, Norlander \& Palmer (2019) di era digital, literasi informasi tetap membutuhkan literasi data, karena ketika seseorang membaca, bekerja, bermain atau hanya menjelajahi internet maka kita akan terus-menerus mengkonsumsi data dari internet sekaligus kita juga memberikan kontribusi data pribadi ke sistem dan platform internet yang kita gunakan. Aktifitas manusia selama mengakses internet akan terekam ke dalam sistem jaringan, kita dapat memanfaatkan informasi dan data yang tersebar di internet namun tanpa kita sadari bahwa data kita ikut terekam ke sistem jaringan internet. Industrialisasi 4.0 memang memberikan kemudahan karena adanya penggunaan teknologi, di satu sisi kita harus membayar kemudahan yang diterima dengan cara memberikan data pribadi kita secara gratis ke sistem jaringan internet. Tantangan bagi masyarakat pesisir (nelayan) terkait dengan pesatnya penggunaan internet adalah tentang data pribadi yang kemungkinan dapat diakses oleh khalayak luas.

Data pribadi dapat menjadi konsumsi publik karena adanya transaksi antara masyarakat dengan perangkat digital penyedia layanan informasi dan komunikasi. Transaksi ini dapat berubah pendaftaran setiap akan mengakses situs jejaring sosial maupun website lain yang menerapkan sistem pendaftaran. Selain itu data pribadi dapat berupa aktifitasaktifitas masyarakat yang dilakukan melalui internet juga menjadi bagian dari privasi yang perlu dilindungi. Menurut Latumahina (2014) data pribadi diartikan sebagai data yang meliputi identitas pribadi, kode, simbol, huruf atau angka penanda personal seseorang yang bersifat pribadi. Data pribadi yang tersebar melalui internet dapat juga berupa kata-kata status yang tersebar melalui media sosial, komentar, ataupun publikasi lainnya yang sifatnya pribadi yang disebarkan melalui media sosial maupun portal lain juga menjadi data pribadi yang harusnya perlu dilindungi.

Tantangan lain yang harus dihadapi oleh masyarakat pesisir di era internet akan sangat banyak dan memiliki jenis beragam. Akan tetapi untuk menklasifikasikan tantangan ini maka perlu untuk mengetahui terlebih dahulu tentang konsep industrialisasi 4.0. Menurut Bloem dkk (2014) dalam Daribay dkk (2019) menjelaskan bahwa industrialisasi 4.0 atau 
yang dikenal dengan indutri 4.0 adalah adanya implementasi sistem siber/dunia maya (cyber-phisical) secara massal dalam kehidupan dan sistem kerja, serta adanya peningkatan penggunaan sistem otomatisasi di semua proses produksi yang terjadi di sektor industri. Bloem dkk (2014) lebih lanjut menjelaskan bahwa teknologi utama yang digunakan pada era industri 4.0 adalah big data, internet of thing, virtual and augmented reality, 3D Printed, quantum computing, blockchain dan robotization. Tantangan di era industrialisasi 4.0 dapat dilihat dari teknologi yang mulai digunakan, keberadaan teknologi inilah tentu dapat menimbulkan tekanan bagi masyarakat terutama mereka yang belum siap dengan teknologi. Tentu saja perkembangan teknologi akan terus mengalami perbaruan sehingga muncul teknologi-teknologi baru yang masuk ditengah masyarakat. Teknologi yang muncul di era industrialisasi 4.0 seluruhnya dapat memiliki pengaruh signifikan baik yang bersifat positif maupun negatif. Dari teknologi tersebut beberapa diantaranya dapat memberikan tantangan cukup besar bagi masyarakat pesisir, walaupun sebenarnya semua dari komponen teknologi yang dijelaskan diatas memiliki pengaruhnya masing-masing. Adapun teknologi yang dimaksud antara lain, pertama, Big Data. Teknologi ini apabila dikembangkan dengan baik akan menjadi teknologi yang memiliki pengaruh besar terutama bagi dunia industri maupun pemerintahan. Karakteristik masyarakat nelayan yang cenderung tertutup dapat membuat pengaruh big data tidak terlalu berdampak signifikan manakala masyarakat nelayan dapat sangat masif menjaga keamanan informasi yang dimiliki. Pendapat yang sama dikemukan oleh Diaz (2019) yang menjelaskan jika big data membutuhkan adanya perubahan budaya karena nelayan secara tradisional cenderung tidak mau berbagi informasi. Perkembangan big data memang dapat memberikan dampak positif, akan tetapi perkembangan tersebut juga mampu memberikan tantangan besar terutama bagi masyarakat kelas kedua seperti masyarakat yang tinggal di daerah pedesaan dan pesisir pantai. Masyarakat kelas kedua belum tentu memahami konsep big data dengan benar, pemahaman mereka masih terbatas pada teknologi yang mudah diakses, dan membebaskan mereka untuk berinteraksi, mengakses informasi maupun bertransaksi kapan saja. Kurangnya pengetahuan mereka tentang dampak siginifikan yang muncul dari teknologi membuat masyarakat akan sangat terbuka dengan data pribadi yang mereka miliki. Teknologi membuat kontrol manusia terhadap data pribadi semakin berkurang, imbasnya masyarakat cenderung memberikan dengan mudah data pribadi mereka supaya dapat digunakan untuk mengakses portal-portal online yang mereka temui melalui internet. 
Big Data harus disikapi dengan benar oleh masyarakat dan khususnya pemerintah pusat maupun daerah. Keberadaan Undang-Undang Penyalagunaan Data memang menjadi salah satu solusi untuk membatasi masyarakat supaya tidak terbuka menggunakan datanya di internet, namun yang lebih penting disini adalah sosialisasi, pelatihan serta pendampingan secara berkala pada masyarakat-masyarakat yang tinggal di daerah pinggiran. Kebiasaan masyarakat pesisir yang gemar mengakses internet tanpa memahami fungsi dan peran dari teknologi yang digunakan tentu akan menjadi ladang data yang cukup besar untuk di panen oleh operator-operator nakal. Hal inilah yang menjadi tantangan bagi pemerintah serta masyarakat pada umumnya untuk melakukan kolaborasi supaya muncul solusi untuk menghadapi tantangan tersebut.

Kedua, Internet of Thing, merupakan teknologi yang mulai banyak diterapkan di era industrialisasi. Internet of Thing dijelaskan oleh $\mathrm{Lu} \&$ Neng dalam Cavdar \& Ebrahimpour (2019) sebagai sebuah infrastruktur publik yang memiliki kemampuan self-configuring seperti teknologi sensor, komunikasi nirkabel, jaringan, dan kemampuan pemrosesan informasi. Internet of Thing mengajak masyarakat untuk berpikir cepat, menyelesaikan permasalahan berbasis internet, transaksional berbasis internet, berinteraksi menggunakan internet dan sebagainya. Bagi masyarakat pesisir waktu adalah uang, kehidupannya ditentukan oleh kondisi alam yang tidak menentu. Mereka hidup dan bekerja mengandalkan hasil laut, disatu sisi apabila kondisi alam sedang mengalami pergantian musim maka kebanyakan masyarakat pesisir tidak dapat berlaut sehingga mata pencaharian mereka beralih sementara menjadi buruh, atau tetap memaksakan diri melaut. Internet of Thing menjadi tantangan yang berat karena pola berpikir masyarakat pesisir sangat berbeda dengan masyarakat lain yang tinggal di kota maupun di daerah berkembang. Masyarakat pesisir cenderung berperan sebagai pengguna teknologi, mereka tentu memiliki smartphone namun cenderung dipakai untuk mengakses media sosial. Masyarakat pesisir belum memiliki pemahaman secara holistik terhadap teknologi informasi, pengetahuan mereka terhadap internet masih sangat terbatas sehingga berat bagi masyarakat pesisir untuk dapat berpikir dengan konsep internet of thing.

Internet of thing tentu sangat cocok diterapkan pada masyarakat yang sudah terbiasa menggunakan internet sebagai alat dalam menjalankan rutinitas sehari-hari, masyarakat kota tentu sangat siap dengan tantangan ToT (Internet of Thing), karena secara pendapatan juga mencukupi untuk berlangganan internet. Selain itu, akses jaringan internet juga mudah 
didapatkan sehingga masyarakat sangat siang menghadapi tantangan tersebut. Hal berbeda terjadi di masyarakat pesisir, dimana pendapatannya sangat terbatas sehingga berlangganan internet tidak menjadi kebutuhan dasar yang harus diutamakan seperti halnya masyarakat perkotaan. Selain itu kepemilikan perangkat (gadget) juga tidak merata karena hanya individu-individu tertentu saja yang memiliki gadget dengan yang dapat mengakses internet setiap waktu. Penggunaan handphone oleh masyarakat pesisir biasanya hanya digunakan sebatas untuk mengirim dan menerima pesan singkat (SMS) dan berkomunikasi via telepon.

Ketiga, Robotization. Tantangan selanjutnya bagi masyarakat pesisir di era industrialisasi 4.0. Penggunaan robot disini bukan untuk menggantikan peran masyarakat pesisir dalam hal mencari ikan di laut, akan tetapi robotisasi disini adalah semakin banyak industri yang mulai menggunakan mesin untuk mempercepat proses produksi. Robotisasi pada sektor industri tentu dapat mengurangi ketergantungan industri terhadap tenaga manusia (buruh) sehingga industrialisasi 4.0 dapat menutup peluang masyarakat pesisir yang membutuhkan tambahan penghasilan dengan cara bekerja di sektor industri. Robotisasi pada sektor industri membuat masyarakat pesisir harus tetap memilih bekerja dengan alam karena peluang mereka perlahan tertutup untuk bekerja di sektor industri. Industri hanya mencari orang yang memiliki kompetensi dan keterampilan, sedangkan masyarakat pesisir kurang memiliki kompetensi diluar pengalaman mereka sebagai pelaut. Walaupun masih ada kemungkinan untuk mereka bekerja di sektor industri namun upah yang diterima juga masih sangat rendah karena alasan kurangnya keterampilan yang dimiliki oleh masyarakat pesisir.

Tantangan robotisasi akan sangat cepat dirasakan oleh masyarakat pesisir karena sudah banyak lahan yang dibeli untuk pendirian industri. Kasus ini dapat dilihat di daerah pesisir Jawa Timur seperti di Kabupaten Lamongan, Gresik dan Tuban mulai banyak ditemukan industri yang berdiri di daerah pesisir. Industrialisasi 4.0 yang mengutaman keandalan sistem robotisasi dan otomatisasi tentunya dapat menjadi tantangan sekaligus permasalahan yang besar bagi masyarakat pesisir, keberadaan industri di area pesisir dapat mempengaruhi kondisi lingkungan karena akan ada kemungkinan polusi yang berujung pada pencemaran lingkungan. Kondisi seperti ini tentunya tidak akan diinginkan oleh masyarakat pesisir karena mata pencaharian mereka seluruhnya berasal dari sektor laut. 


\section{KESIMPULAN DAN SARAN}

Kurangnya pendidikan dan pengetahuan terhadap internet dapat membuat masyarakat pesisir menjadi kehilangan kontrol terhadap penggunaan internet secara bijak. Kebijakan implementasi program literasi data perlu diberikan pada masyarakat pesisir terutama terhadap pentingnya menjaga data dan informasi pribadi saat berjejaring melalui internet. Penerapan literasi data pada masyarakat pesisir tentunya serupa dengan penerapan literasi data pada kelompok lain meliputi peningkatan keterampilan membaca data, menganalisis data, menseleksi data, memiliki media sebaran data yang tepat, dan kemampuan menyampaikan data secara cepat dan tepat sasaran. Tantangan perubahan tentunya akan berimbas pada masyarakat secara luas, akan tetapi bagi mereka yang sudah melakukan investasi pengetahuan tentang pentingnya internet, teknologi informasi dan data tentu akan sangat mudah menghadapi tantangan jaman. Literasi data hanyalah salah satu dari banyaknya program penguatan dan bimbingan bagi masyarakat supaya dapat bersaing dan bertahan di era industrialisasi 4.0. Tantangan industrialisasi di generasi terbaru bukan sekedar berhadapan dengan perkembangan internet yang pesat, ataupun sebaran data dan informasi yang membanjiri dunia siber, namun masyarakat pesisir juga harus berhadapan dengan masyarakat lain yang lebih siap untuk tidak terkikis oleh perkembangan peradaban.

Saran utama bagi masyarakat pesisir di tengah gelombang kemajuan peradaban yang semakin canggih ialah perlu adanya penguatan keterampilan yang dilakukan oleh masyarakat. Selain itu pemerintah juga harus ikut berperan terutama dalam hal penguatan kebijakan yang berfokus pada pengembangan sumber daya manusia khususnya pada masyarakat pesisir.

\section{DAFTAR PUSTAKA}

Alfarizi, M. K. (2019). Survei Kepemilikan Smartphone, Indonesia Peringkat ke-24. Tempo. https://tekno.tempo.co/read/1181645/survei-kepemilikan-smartphone-indonesia-peringkat-ke-24

Alfin, J. (2018). Membangun Budaya Literasi Dalam Pembelajaran Bahasa Indonesia Menghadapi Era Revolusi Industri 4.0. PENTAS: Jurnal Ilmiah Pendidikan Bahasa dan Sastra Indonesia, 4(2), 60-66.

Buot, M. M., \& Dulca, M. Z. C. (2019). An Index to Determine Community Wellbeing Along Coastal Community in Leyte, Philippines. EnvironmentAsia, 12(1). https://doi.org/10.14456/ea.2019.7

Cavdar, T., \& Ebrahimpour, N. (2019). Decision-making for small industrial Internet of Things using decision fusion. Turkish Journal of Electrical Engineering \& Computer Sciences, 27(6), 4134-4150. https://doi.org/10.3906/elk-1809-60 
D'Ignazio, C. (2017). Creative Data Literacy: Bridging the Gap Between the Data-Haves and Data-Have Nots. Information Design Journal (IDJ), 23(1), 6-18. https://doi.org/https://doi.org/10.1075/idj.23.1.03dig

Daribay, A., Serikova, A., \& Ukaegbu, I. A. (2019). Industry 4.0: Kazakhstani Industrialization Needs a Global Perspective. Procedia Computer Science, 151, 903-908. https://doi.org/10.1016/j.procs.2019.04.125

Diaz, L. (2019). Big Data: The Future of Sustainable Fisheries. Sea Technology, 60(11). http://eresources.perpusnas.go.id:2072/eds/pdfviewer/pdfviewer?vid=0\&sid=8eb0688c-96a2-4fd8-a5d7bcc91b0a2042\%40sessionmgr102

Efron, S. E., \& Ravid, R. (2019). Writing the Literature Review: a Practical Guide. The Guilford Press.

Erwin Jr, R. W. (2015). Data Literacy: Real-World Learning Through Problem-Solving With Data Sets. American Secondary Education, 43(2), 18-26. http://eresources.perpusnas.go.id:2367/eds/detail/detail?vid=0\&sid=9c53e5dc-5568-480f-8f023ff86a6f4cd7@sdc-v-sessmgr02\&bdata=JnNpdGU9ZWRzLWxpdmU=\#AN=103298736\&db=ehh

Fatwa, M. S. (2016). Dinamika Pendidikan Masyarakat Nelayan di Desa Pandangan Wetan Kecamatan Kragan Kabupaten Rembang. Forum Ilmu Sosial, 43(01), 38-45. https://doi.org/https://doi.org/10.15294/fis.v43i1.9345

Fontichiaro, K. (2019). Data Literacy: Negotiating Convenience and Data Privacy. Teacher Librarian, 47(1), 51-54. http://e-resources.perpusnas.go.id:2367/eds/detail/detail?vid=0\&sid=fa684846-c3b0-412c-a1ef0092ab7e4fd9@sessionmgr4008\&bdata=JnNpdGU9ZWRzLWxpdmU=\#AN=140246725\&db=lih

Freire, P., \& Macedo, D. (1987). Literacy: Reading the Word \& the World. Routledge and Keagen Paul Ltd.

Javorszky, Ferenc, Tibor Koltay, and Péter Murányi. 2019. "Data Literacy Skills of Hungarian Researchers.” Library Review / Konyvtari Figyelo, no. $\quad 3$ : $1 . \quad$ http://eresources.perpusnas.go.id:2367/eds/detail/detail?vid=0\&sid=2d617f73-f191-4b02-940d-

fa17337b0aaf\%40sdc-v-sessmgr01\&bdata=JnNpdGU9ZWRzLWxpdmU\%3d\#AN=140353418\&db=lih.

Kitchin, R. (2014). The Data Revolution: Big Data, Data Open, Data Insfrastructure and Their Consequences. SAGE Publications.

Kusnadi, Sumardjono, Sulistyowati, H., Koesoemawati, D. J., Prasodjo, A., Subjan, W., Saputra, H. S. P., Adzkiyak, Winarno, L., \& Rahman, T. (2007). Strategi Hidup Masyarakat Nelayan. LKiS.

Latumahina, R. E. (2014). Aspek Hukum Perlindungan Data Pribadi di Dunia Maya. Jurnal Gema Aktualita, 03(02). http://dspace.uphsurabaya.ac.id:8080/xmlui/bitstream/handle/123456789/92/Aspek Hukum Perlindungan Data Pribadi di Dunia Maya.pdf?sequence=1\&isAllowed=y

Murray-Rust, C., Doshi, A., Forrest, J., Mi, X., \& Valk, A. (2019). Data Literacy as a Pathway to Data Science at Georgia Tech. Research Library Issues, 298, 6-15. https://doi.org/https://doi.org/10.29242/rli.298.2.

Potter, J., \& McDougall, J. (2017). Digital Media, Culture and Education: Theorising Third Space Literacies. Macmillian Publisher.

Setriawati, B., Suryaningsih, \& Solina, E. (2018). Manfaat Internet Bagi Nelayan Kelurahan Tanjung Unggat. Repositori Umrah. http://repository.umrah.ac.id/709/1/jurnal bety.pdf

Throgmorton, K., Norlander, B., \& Palmer, C. (2019). Open Data Literacy and the Library. Alki, 35(2), $27-29$. http://e-resources.perpusnas.go.id:2367/eds/detail/detail?vid=0\&sid=3bdcffcc-be95-42c2-af0b-

bada6f4064a2@sdc-v-sessmgr03\&bdata=JnNpdGU9ZWRzLWxpdmU=\#AN=137763300\&db=lih 
Tristania, R. A. . (2016). Mengembangkan Peran Edukasi dan Diseminasi Informasi Oleh Penyuluh Perikanan Bagi Masyarakat Nelayan di Kabupaten Serdang Bedagai. Jurnal Penelitian Komunikasi Dan Pengembangan, 17(01), 61-76. https://doi.org/http://dx.doi.org/10.31346/jpikom.v17i1.1358

Wardani, A. S. (2020). Jumlah Pengguna Domain .id Salip co.id - Tekno Liputan6.com. Liputan 6. https://www.liputan6.com/tekno/read/4166052/jumlah-pengguna-domain-id-salip-coid

Yun Dai. (2019). How many ways can we teach data literacy? IASSIST Quarterly, 43(4), 1-11. http://eresources.perpusnas.go.id:2072/eds/pdfviewer/pdfviewer?vid=0\&sid=81300ab8-0fb3-4497-9c8b43f41be9ba3a\%40sessionmgr 102 